\title{
periferio
}

\section{CONHECENDO O CRIAAD DE NOVA IGUAÇU, SEUS SUJEITOS E SUAS TENSÕES RACIAIS}

\author{
Priscila Duarte dos Reis ${ }^{1}$ \\ Universidade Federal Rural do Rio de Janeiro
}

\section{Resumo}

Este trabalho possui como objetivos, a partir de uma breve exposição e uma análise, apresentar e dar mais visibilidade ao CRIAAD Nova Iguaçu, aos indivíduos que ali se encontram e suas inter-relações, buscando compreender como ocorrem as tensões com motivações raciais nesta unidade e analisar de que forma atuam os agentes públicos responsáveis pelos adolescentes nesta instituição para combater e prevenir tais atitudes. Objetiva, também, mostrar a necessidade de se refletir sobre os termos cidadania e juventude a partir de um referencial de identidade étnico racial. É possível dizer que esta análise é bastante sucinta tendo em vista a riqueza e a quantidade de informações trazidas pelos jovens socioeducandos e agentes públicos quando entrevistados e também quando apenas observados. Para este artigo fiz um recorte com apenas algumas informações, dentre as muitas, obtidas através da observação do campo e de entrevistas realizadas com alguns servidores da unidade em questão.

Palavras-chave: socioeducação; sujeitos; Baixada Fluminense; relações étnico-raciais

\footnotetext{
${ }^{1}$ Bacharel em Direito, especialista em História e Cultura Afro brasileira e Africana (UFRRJ), Mestranda em Educação, Cultura e Comunicação em Periferias Urbanas (UERJ/FEBF), Chefe do Setor de Promoção de Eventos e Ações Sociais da UFRRJ.
} 


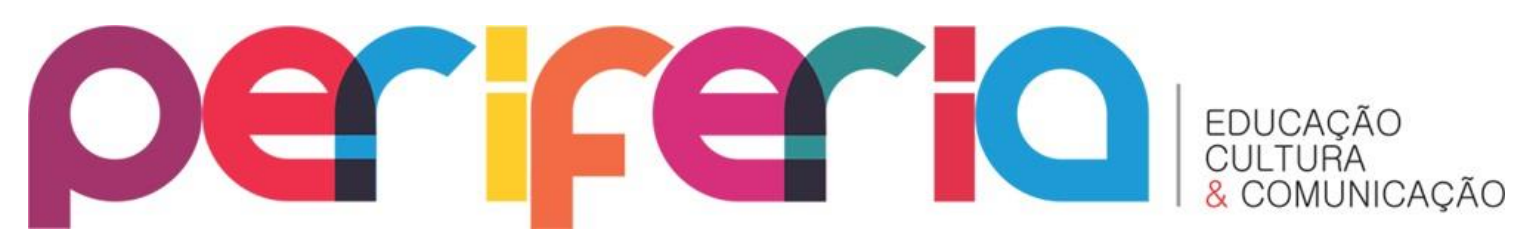

\title{
KNOWING THE CRIAAD NOVA IGUAÇU, ITS SUBJECTS AND THEIR RACIAL TENSIONS
}

\begin{abstract}
This work aims, from a brief exposition and a subtle analysis, to give more visibility to the CRIAAD Nova Iguaçu, to the internals and their interrelationships, trying to understand if and how there are tensions with racial motivations in this unit and to analyze if and how the public agents responsible for teenagers in this institution work to combat and prevent such attitudes. It also aims to show the need to reflect on the terms citizenship and youth from a referencial of ethnic racial identity It is possible to say that this analysis is very succinct in view of the amount of informations brought by educators and agents when interviewed and also when only observed. For this article I made a clipping with some informations obtained in interviews and observation in the field.
\end{abstract}

Keywords: socioeducation, subjects, Baixada Fluminense, ethnic-racial relations 


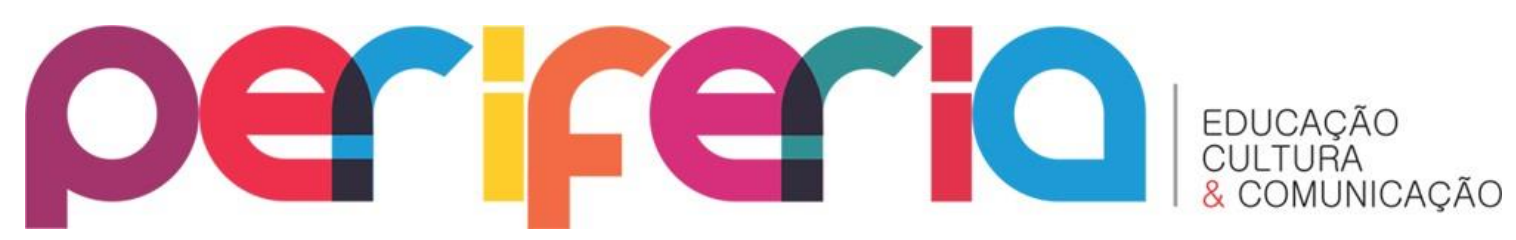

\section{CONSIDERAÇÕES INICIAIS}

Este artigo tem por objetivo descrever e apresentar o local de pesquisa, seus sujeitos e verificar se existem manifestações de cunho racista em determinada unidade do Departamento Geral de Ações Socioeducativas, de que forma se apresentam e como esta situação é tratada pelos agentes públicos atuantes nesta instituição.

O Centro de Recursos Integrados de Atendimento ao Adolescente (doravante denominado CRIAAD) é o órgão do Departamento Geral de Ações Sócio educativas (DEGASE), vinculado à Secretaria de Educação do Estado do Rio de Janeiro (SEEDUC), responsável pela execução da medida de semiliberdade2, imposta por sentença judicial, aos adolescentes que em algum momento de suas vidas estiveram em conflito com a lei.

Esta modalidade está prevista no artigo 120 do Estatuto da Criança e do Adolescente (ECA), que prevê que a medida em questão poderá ser aplicada de início ou como forma de transição da internação (esta que, na prática, se assemelha ao regime fechado de uma pena de prisão) para a liberdade assistida.

Sendo assim, nestes locais se encontram meninos e meninas (no caso da unidade em estudo, apenas adolescentes do sexo masculino) que anteriormente estavam cumprindo sentença em outras unidades do DEGASE voltadas a total restrição de liberdade (principalmente, Educandário Santo Expedito- Bangú, Centro de Socioeducação Dom Bosco e Escola João Luiz Alves - Itha do Governador, Centro de Atendimento Integrado- Belford Roxo e Centro de Socioeducação Irmã Asunción de La Gándara Ustara- Volta Redonda) e outros que foram submetidos imediatamente à semiliberdade.

$2 \mathrm{Na}$ semiliberdade os adolescentes que cumprem tal medida ficam sob regime de semiinternato de segunda até sexta feira na unidade, podendo sair para exercer algum ofício (quando autorizado) e para estudar, devendo, após essas atividades, retornar ao CRIAAD. São liberados para retornarem às suas residências (acompanhado de um responsável) na sexta feira (ou feriados prolongados), após determinado horário, devendo retornar no próximo dia útil pela manhã. 


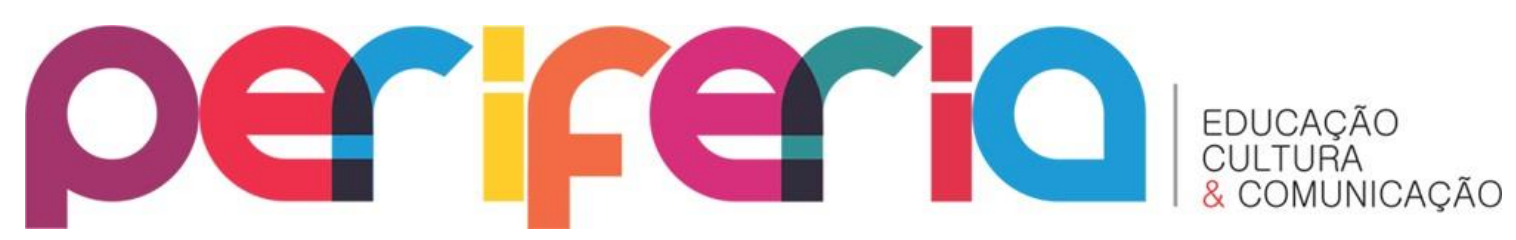

\section{CONHECENDO A UNIDADE E SEUS SUJEITOS}

Antes de avançarmos para o mérito deste artigo, faz-se necessário situar e conceituar a localidade onde esta instituição se encontra, tendo em vista as ligações existentes dos sujeitos que lá se encontram com o território onde estão e de onde muitos são. É imprescindível, também, descrevermos a trajetória da unidade ao longo do tempo, tendo em vista a importância deste esclarecimento para que compreendamos determinados acontecimentos.

Apesar da necessidade de nos situarmos em relação a este último componente (tempo), faremos isto de forma transversal, durante todo o texto, para que a escrita se torne mais compreensível, ao passo que o primeiro componente, território, conceituaremos de forma direta, como veremos a seguir.

O CRIAAD sobre o qual versa este trabalho se situa à rua Venezuela, sem número, bairro Metrópole, município de Nova Iguaçu, encontrando-se, assim, em uma Região denominada, por muitos, como Baixada Fluminense. Esta nomenclatura possui diversos contornos, de acordo com o aspecto a ser observado pelo pesquisador. Há acepções geográficas, sociais, políticas, culturais e econômicas, e por este motivo não é das tarefas mais fáceis conceituar tal localidade, mas conforme explicita Simões (2011, p.31):

\footnotetext{
Definir e delimitar uma região não é uma tarefa simples e esse capítulo introdutório demonstrou isso. Contudo não podemos fugir a nossa responsabilidade de, no mínimo, delimitar o nosso objeto de estudo que é a baixada fluminense. 0 conceito e limites desta região contidos neste livro tão somente possuem o objetivo didático de traçar os limites da nossa pesquisa e da nossa análise, para podermos dialogar com os futuros leitores.
}

Levando em consideração que os agentes públicos devem ter como um dos parâmetros o local de residência dos adolescentes na hora de fixar a localidade para onde o jovem será encaminhado para cumprir sua medida sócio educativa, torna-se indispensável a conceituação e constituição 


\section{periferio}

geográfica desta região.

Para fins deste trabalho utilizaremos o conceito adotado pela FUNDREM (Fundação para o Desenvolvimento da Região Metropolitana do Rio de Janeiro) ao que determinou de UUIO (Unidades Urbanas Integradas a Oeste) do Rio de Janeiro. Conforme esse critério, a Baixada Fluminense seria uma área composta pelos municípios Duque de Caxias, Nilópolis, Nova Iguaçu Belford Roxo, Mesquita, Queimados, Japeri e São João de Meriti. Utilizaremos esta conceituação tendo em vista ser a que mais se das localidades de origem dos adolescentes presentes na unidade em questão, visto que a maioria dos meninos são oriundos de Mesquita, Nova Iguaçu, Japeri, São João de Meriti, Belford Roxo, Queimados, Seropédica e até mesmo Itaguaí e Paracambi.

Apesar de muitos serem provenientes destes municípios, que de acordo com a concepção geográfica adotada do termo fazem parte da Baixada, há ainda meninos (poucos) oriundos dos subúrbios do Rio de Janeiro, que por algum motivo que vai desde superlotação até problemas com facções, ou por alguma outra causa não sabida e não oficial, não são direcionados às unidades contíguas às suas residências.

Sobre este fato, há importante observação por parte do Professor ALVES (2003, p.15), onde ele relata que há quem faça confusões acerca dos aspectos geográficos, sociais e políticos ao se delimitar fronteiras para a Baixada Fluminense. Analisando com este olhar, pode ser que o fato de termos um ou outro menino do subúrbio carioca cumprindo medida em uma unidade situada na Baixada Fluminense nada mais seja do que uma acepção social dos limites desta região.

Observando a temática localidade de uma forma mais ampla, surge um dado curioso para esta discussão não apenas geográfica, mas também social, que se consubstancia no fato de as unidades do DEGASE destinadas a semiliberdade serem, em sua maioria, em endereços cujos indicativos de renda, cor e classe sejam muito próximos.

Apenas com o intuito de dar mais corpo a esta afirmação, seguem os endereços das unidades do estado do Rio de Janeiro: CRIAAD Ilha do 


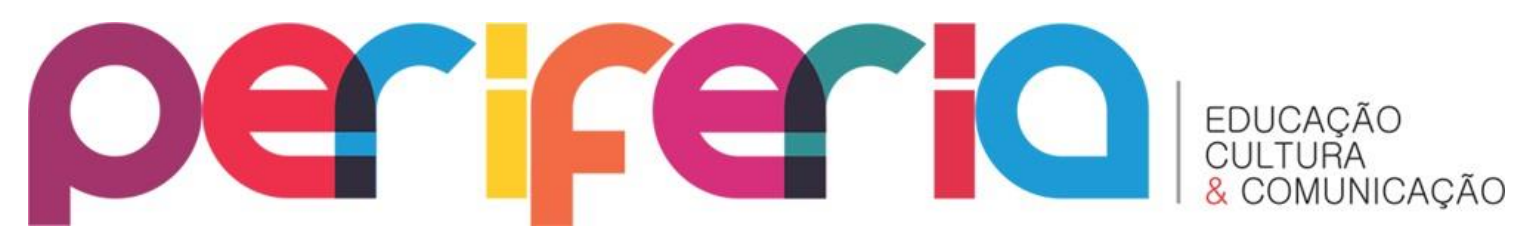

Governador Estrada do Caricó, 111, Galeão, CRIAAD Bangu Rua Sidney, s/n, Bangu, CRIAAD Penha, CRIAAD Ricardo de Albuquerque, CRIAAD Santa Cruz, CRIAAD Niterói, localizado no bairro Barreto, CRIAAD São Gonçalo, CRIAAD Duque de Caxias, localizado no bairro Sarapui, CRIAAD Nilópolis, no bairro Cabuis, CRIAAD Nova Iguaçu, bairro Metrópole (próximo ao Pombal do IBC), CRIAAD Barra Mansa, no bairro Bom Pastor, CRIAAD Volta Redonda, na Vila Mury, CRIAAD Cabo Frio, no bairro Jacaré, CRIAAD Macaé, bairro Novo Visconde, CRIAAD Campos dos Goytacazes, bairro Pecuária, CRIAAD Nova Friburgo, no bairro Prado, CRIAAD Teresópolis, no bairro Fonte Santa.

Como bem se pode observar, os endereços acima não são os dos cartões postais, nem os da high society carioca. A partir desta observação empírica, breve e superficial, podemos constatar que as localidades onde se encontram estas unidades, se assemelham, em alguns aspectos à Baixada. Sendo assim, aquela afirmação do professor José Cláudio se mostra muito bem exemplificada quando nos deparamos com o fato de meninos moradores do subúrbio do Rio serem lotados, por exemplo, em uma unidade em Nova Iguaçu.

Podemos ver que houve um esforço por parte do poder público em colocar, por exemplo, escolas, praças, museus, teatros, universidades e bibliotecas em maior quantidade nas áreas onde residem pessoas de maior poder aquisitivo e prestígio, do que em áreas onde residem os trabalhadores, pessoas com menor poder aquisitivo, reservando a estas os CRIAAD's, os presídios, os aterros sanitários e um menor número de escolas, com poucos recursos e investimentos, teatros, bibliotecas, entre outras opções de lazer.

Diante do exposto acima não é de se espantar que para o agente público que define a lotação do adolescente em conflito com a lei, por vezes, pouco importe se estará na Penha ou em Nova Iguaçu. Ainda hoje há quem cometa essas confusões, de forma intencional ou não. A respeito desta constatação, temos uma análise de ROCHA (2013, p.7-8) que a respeito das diversas acepções de Baixada Fluminense, aponta que: 


\section{periferio}

Hoje, associada a uma representação hegemônica de pobreza urbana, miséria, violência social, é comumente personificada e reificada em discursos políticos cuja sua menção permite um (re)arranjo de poder. Entendemos que esta Baixada se constitui como uma representação territorial de poder (ROCHA, 2011), lócus de uma geografia política, onde práticas e representações permitem a apropriação deste território no urbano metropolitano fluminense e que criam um problema territorial sobre 0 uso ou negação desta representação hegemônica.

Ainda refletindo sobre a lotação de alguns adolescentes não atenderem ao critério domicílio, vale ressaltar que apesar de praticamente todos os assistidos do CRIAAD Nova Iguaçu pertencerem a um contexto urbano semelhante, estes não são idênticos (Baixada Fluminense x Subúrbio do Rio). Apesar de pertencerem a localidades estigmatizadas pela mídia e partilharem de sentimentos em comum, possuem, também, memórias distintas, identidades distintas.

A unidade sobre a qual este trabalho se debruça foi criada no ano de 1988 sob a denominação CRIAM-Centro Regional de Integração e Assistência ao Menor - e logo após a implementação do Estatuto da Criança e do Adolescente (1990) teve sua nomenclatura alterada, tendo em vista a substituição da palavra "menor" por "adolescente", devido ao termo anterior ter ganhado conotação pejorativa, passando assim a se chamar CRIAAD. Apesar da mudança de nome suas funções continuaram as mesmas.

No ano de 2009 a unidade recebeu uma reforma geral, com mudança no layout de forma a tornar-se um panóptico, aquele ao qual Foucault faz referência. A arquitetura atual permite uma certa distribuição concertada dos corpos dos adolescentes, "das superfícies, das luzes, dos olhares; numa aparelhagem cujos mecanismos internos produzem a relação na qual se encontram presos os indivíduos”. (FOUCAULT, 1996, p.178).

Para a confecção deste trabalho foram feitas entrevistas, realizadas através de conversas semi direcionadas, com servidores da unidade (psicóloga, pedagogo e a diretora da unidade). Minha entrada no campo não 


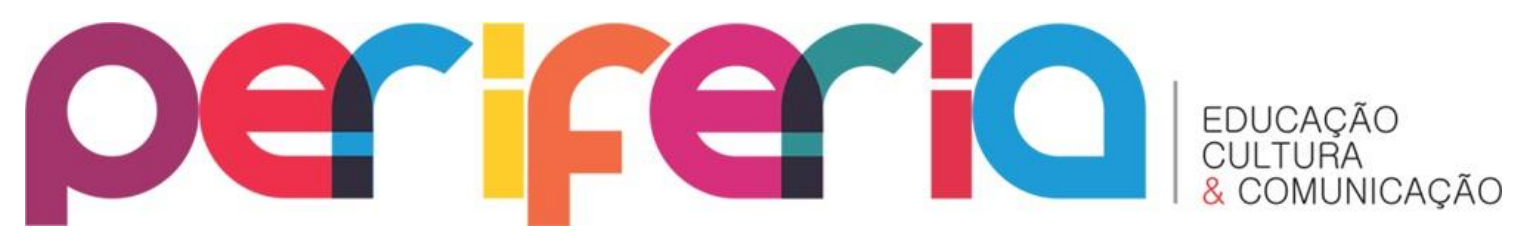

obteve entraves, tendo em vista o fato de já realizar há bastante tempo um projeto de extensão, do qual sou coordenadora de campo, junto aos meninos desta instituição e por já ter certo grau de aproximação com os sujeitos ali presentes (funcionários e socioeducandos), que em todo momento buscaram colaborar com esta pesquisa.

Os nomes dos informantes foram ocultados deste trabalho, tendo em vista o fato de se tratar de um local responsável por meninos menores de idade e por ser relacionado, também, com o ofício de agentes públicos, submetidos a código de ética e disciplina.

No momento no qual fiz o levantamento numérico da pesquisa, havia cinquenta e dois (52) meninos na unidade e apesar deste número elevado e crescente, a unidade possui capacidade para apenas trinta e dois (32) jovens. De acordo com a lei, a medida socioeducativa tem de ser cumprida em local próximo à residência do adolescente, mas devido a problemas relacionados a superlotação e rivalidade entre facções, este mandamento nem sempre pode ser observado. No caso do nosso campo de pesquisa, a maioria dos meninos pertence a Região da Baixada Fluminense, conforme dito acima, mas há meninos pertencentes a dez comarcas diferentes (entre eles há três meninos oriundos da capital do estado).

Em nossa unidade só existem meninos, por ser uma unidade masculina, e todos são pertencentes ao Comando Vermelho (C.V). Desta forma, nenhum menino de outra facção que seja da região da Baixada e que cometa ato infracional e tenha que cumprir a semiliberdade, é enviado para o município de Nova Iguaçu. Apesar de a lei não fazer menção a separação por facções, na prática, funciona assim na maioria das unidades. As poucas que fazem esta mistura, dividem os adolescentes, de forma a destinar alojamentos específicos para cada uma.

Se por um lado esta praxe nos parece uma boa ideia, por visar a segurança dos meninos, por outro ela acaba por legitimar a polarização e a rivalidade existentes. Desta maneira, o tema é controverso entre os gestores das unidades, que mesmo algumas vezes não concordando, acabam por aplicá-la. 


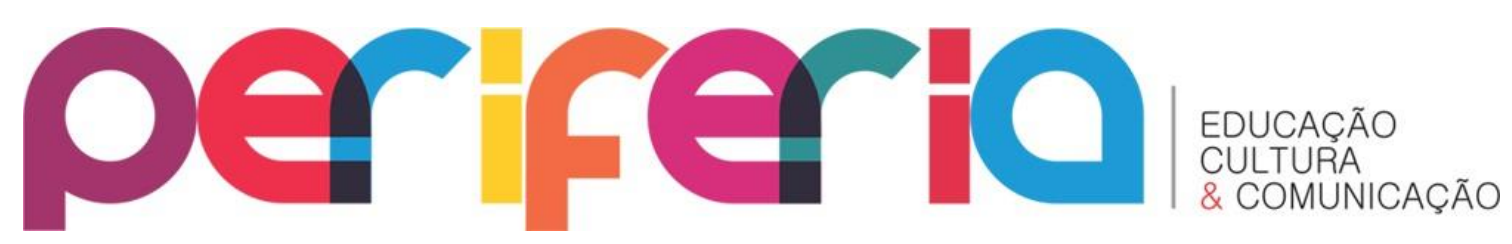

Deste universo de mais de cinquenta meninos, com faixa etária compreendida predominantemente entre 16 e 18 anos, apenas nove (09) encontram-se no ensino médio, dos quais a maioria está matriculada na Educação Para Jovens e Adultos (EJA). Os demais jovens encontram-se no ensino fundamental e muitos, de acordo com levantamento da assistente social da unidade, ainda carecem de letramento.

De acordo com a classificação da assistente social do CRIAAD Nova Iguaçu, que assim os categorizou de acordo com seus sinais diacríticos (pele, cabelo, nariz), 86\% (oitenta e seis por cento) dos adolescentes que ali se encontram são pretos, ou seja, em torno de 44 (quarenta e quatro) meninos são afrobrasileiros, em um universo de 52 (cinquenta e dois). Esta realidade étnico-racial da unidade se repete em todo o estado do Rio de Janeiro, na Região Sudeste e no Brasil como um todo, conforme os seguintes dados constantes nos gráficos 1 e 2 , divulgados no último relatório anual do SINASE, elaborado pela Secretaria de Direitos Humanos e Secretaria Nacional de Promoção dos Direitos da Criança e do Adolescente, divulgado em 2013.

Os dados apresentados nos gráficos a seguir, de acordo com informações dadas pela psicóloga da unidade, são obtidos através do preenchimento de formulários por parte dos próprios sócio educandos. Todos os adolescentes, ao chegarem às unidades, após passarem pela revista, são encaminhados ao atendimento com o serviço social da unidade, onde os meninos inserem as informações necessárias na Ficha de Recepção de Adolescente. Nesta ficha constam campos a serem preenchidos com informações sobre: a) identificação do adolescente b) identificação do responsável c) dados socioeducativos d) dados sobre saúde e ato infracional.

O critério étnico-racial consta no formulário na parte "Identificação do adolescente", e se apresenta de forma a perguntar ao jovem sua cor. Trata-se de uma indagação objetiva que possui como opções de resposta as seguintes: negro, branco, pardo, outro e amarelo, designadas, respectivamente pelas siglas N, B, P, O, A, distintas das classificações adotadas pelo Instituto Brasileiro de Geografia e Estatística - IBGE, que considera negros, brancos, 


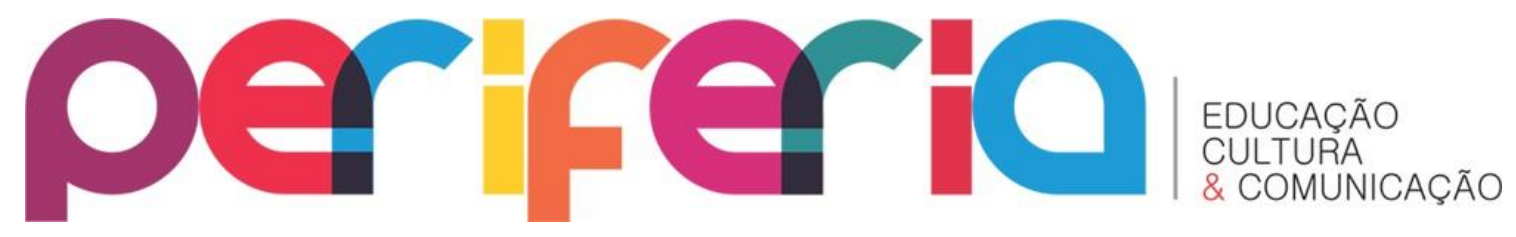

amarelos e indígenas. Partindo do fato deste preenchimento ser feito pelo próprio jovem, podemos afirmar que o critério utilizado pela unidade é o da autodeclaração. Periodicamente estes formulários são enviados à Direção Geral do DEGASE e posteriormente aos órgãos federais competentes a fim de que estes levantamentos anuais sejam feitos.

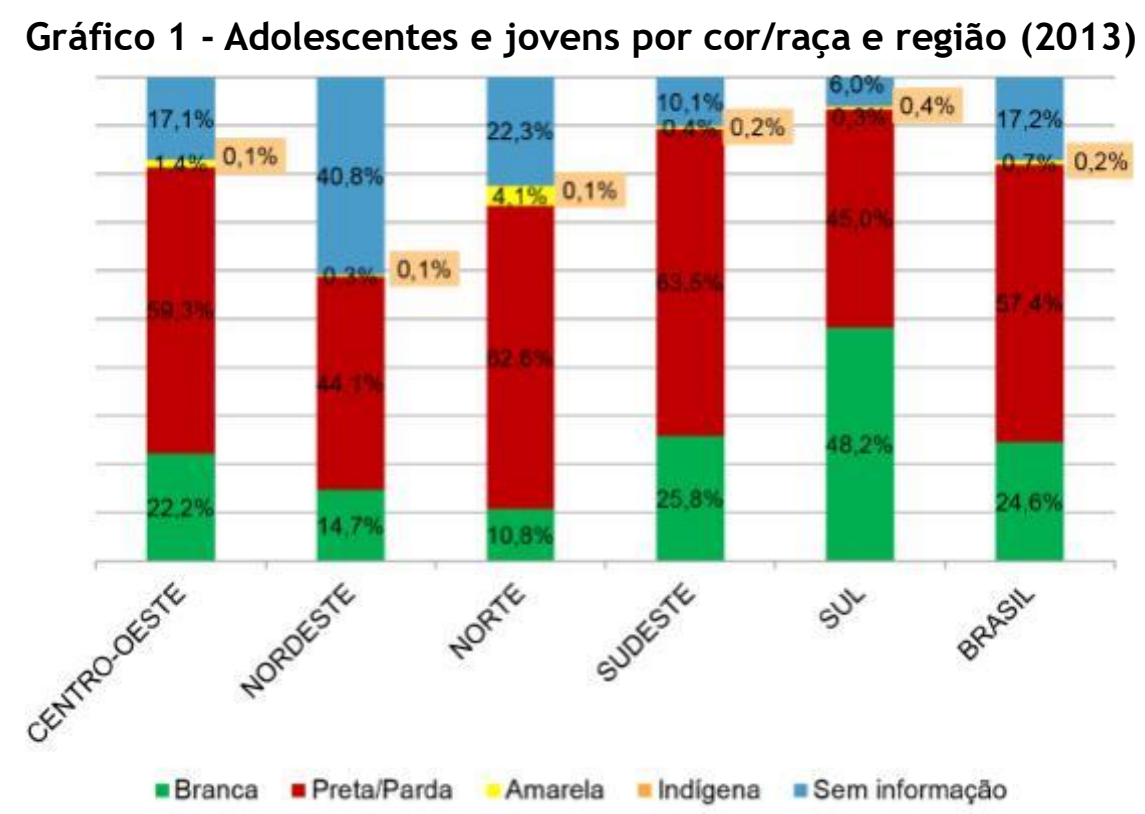

Fonte: Sinase, 2013

\section{Gráfico 2 - Porcentagem de adolescentes e jovens por raça/cor em restrição e privação de liberdade (2013)}

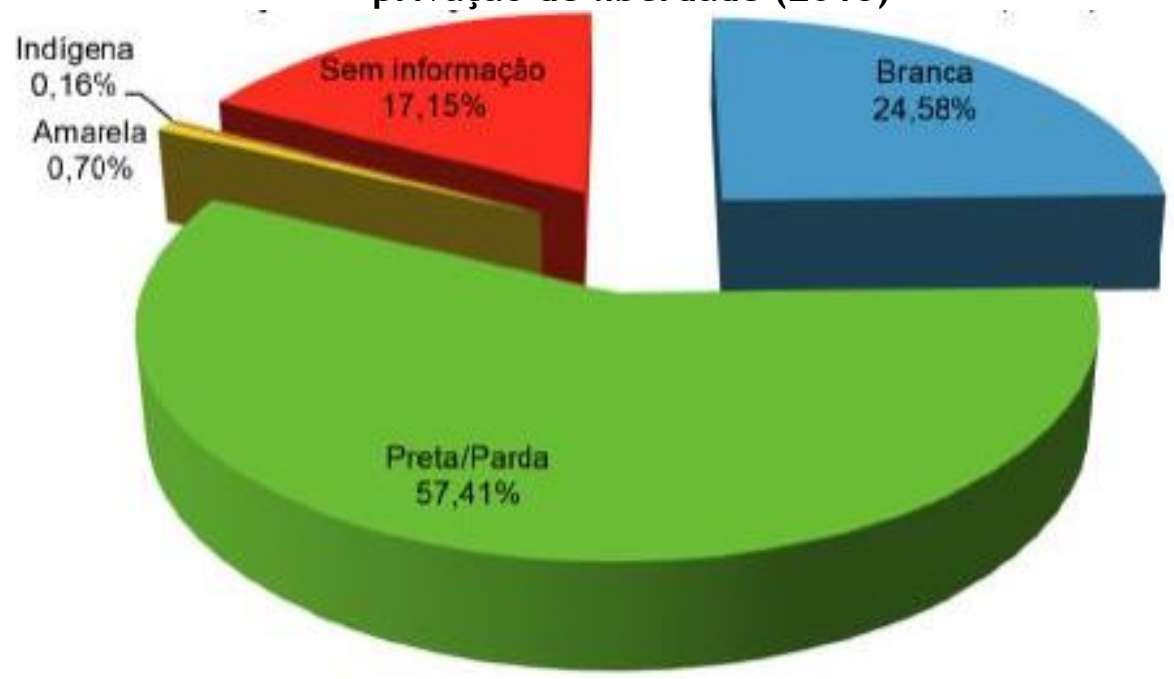

Fonte: Sinase, 2013 


\section{periferio}

No que tange a composição étnico-racial do corpo técnico da unidade, formado por dois assistentes sociais, uma psicóloga e dois pedagogos, há apenas uma negra, em um universo de cinco profissionais. Entre os agentes socioeducativos, formado por servidores, cuja exigência para o preenchimento do cargo é apenas o nível médio de escolaridade e cuja principal função é manter a ordem na unidade, constatei a presença de apenas dois negros, em um quantitativo total observado de cinco agentes.

Cumpre ressaltar que cinco não corresponde ao número total de funcionários deste cargo na unidade, apenas ao número de agentes que eu vi durante todas as vezes em que estive presente na unidade. Sendo assim, pode ser que haja mais funcionários desta categoria lotados na unidade.

Relativamente ao critério renda, segundo entrevista fornecida pela assistente social, cerca de $93 \%$ estão dentro do que se chama "baixa renda". Para esta classificação, conceituaremos como "baixa renda" a definição adotada pela Lei Número 12.799 , de 2013, que versa sobre a isenção de pagamento de taxas para inscrição em processos seletivos de ingresso nos cursos das instituições federais de educação superior e em seu artigo primeiro, parágrafo único, inciso primeiro prevê que "será assegurado isenção total do pagamento das taxas referidas no caput ao candidato que comprovar cumulativamente: I - renda familiar per capita igual ou inferior a um salário mínimo e meio".

Em relação a convivência entre os servidores e os jovens, pode-se dizer que é visivelmente tensa. Seja pelo código de conduta imposto pelo Comando Vermelho, ao qual os meninos estão submetidos e que prevê condutas hostis em relação a agentes socioeducativos, como por exemplo não apertar a mão e não cumprimentar, ou seja, como uma forma de reagir a própria postura, segundo os meninos, "arrogante" dos agentes, que constantemente se dirigem aos meninos de forma a ridicularizá-los e muitas vezes com posturas humilhantes.

A respeito deste comportamento, lanço mão dos ensinamentos de Levi, 


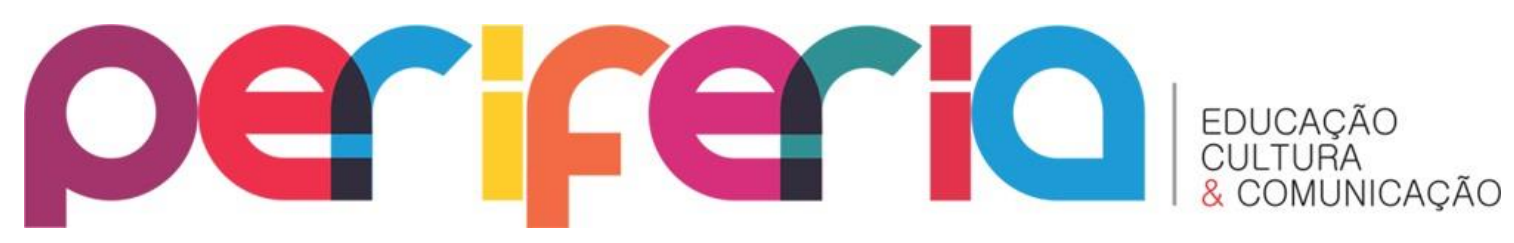

(1992, p.135) ao alegar que a proposta desta menção ao código do C.V. e à atitude dos meninos não é defender este código, ou justificá-lo, mas analisálo através de uma outra perspectiva, para tentar alcançar "uma descrição mais realista de comportamento humano, empregando um modelo de ação e conflito do homem no mundo que reconhece sua - relativa- liberdade além, mas não fora das limitações dos sistemas normativos, prescritivos e opressivos."

Acerca destas posturas dos agentes socioeducativos, cito algumas que registrei em um diário de campo durante uma atividade na casa. Ao chegarmos à unidade arrumamos a sala de vídeo para darmos início a exibição de um documentário denominado Hiato, para posteriormente fazermos um debate acerca de preconceito, renda e classe. Ao finalizarmos a arrumação, solicitamos aos agentes que liberassem os meninos dos alojamentos a fim de que eles se dirigissem ao local da exibição.

Estranhamente o agente chamou os rapazes, se colocou na porta da sala e à medida em que os jovens adentravam ao local, ele fazia comentários jocosos sobre os mesmos.

Em um outro momento eu e outras meninas do projeto flagramos um agente comentando com o outro servidor a seguinte frase: “como a casa está lotada e estamos com falta de papel higiênico, enquanto os meninos assistem ao filme, bora pegar todos os papéis higiênicos dos banheiros deles e guardar no meu armário. Antes eles do que eu sem papel".

Destaco os acontecimentos acima a fim de demonstrar, de forma bem superficial, como se dão as relações entre estes sujeitos e os tutelados, sem pretensão de identificar causa ou efeito, apenas mostrando os fluxos de relações lá existentes, onde as causas e os efeitos se confundem. Viso, assim, apresentar um pouco melhor o nosso campo de pesquisa, bem como as relações de poder e as subjetividades presentes neste local, que se tornam extremamente simbólicas e determinantes para o conhecimento da unidade, que é rotulada como uma filial sui generis dentro do sistema socioeducativo do Rio de Janeiro, justamente por ser fortemente marcada pela disciplina 


\section{periferio}

rígida imposta pela diretora e reproduzida por seus agentes subordinados.

Antes de continuar esta discussão gostaria de deixar bem claro, novamente, que o intuito deste artigo não é culpabilizar agentes, denunciar condutas, ou dar alguma indulgência, desculpas ou justificativas para as atitudes cometidas pelos adolescentes, que como todos sabemos também não são das mais amáveis para com os agentes do Estado. 0 teor dos mandamentos do próprio Comando Vermelho, ao qual todos estão submetidos, deixa isso muito claro. 0 intuito desta narrativa é apenas mostrar um contraponto, o detalhe, aquilo que os jornais, as mídias televisivas não mostram com a mesma frequência de outras atitudes.

Acerca da conduta violenta dos jovens sob tutela do DEGASE já temos muitas narrativas, feitas por terceiros, e com local de destaque em nossa sociedade. Apesar de trazer esta outra visão de forma bem breve, tendo em vista o fato desta escrita ser apenas um artigo, e não um livro ou uma monografia, considero importante trazê-las para que possamos ter uma visão a partir outra escala, focada em relações do dia a dia, entre agentes/sujeitos que não são os que obtém, normalmente, o protagonismo e a voz da narrativa de suas histórias. Conforme muito bem explanado por Bezerra (2010, p.21):

o procedimento da escala, deve ser encarado como uma perspectiva metodológica bastante eficaz, mas não como um pressuposto teórico, como nos adverte Giovanni Levi. Não basta apenas reduzir a escala para se ter uma visão mais apurada do processo estudado. Através deste método, é possível analisar as irredutibilidades dos indivíduos, as contradições na geração da mudança social e as discrepâncias que emanam dos sistemas normativos. Seguindo o princípio mais comum da microanálise, a investigação mais intensa, com um olhar mais próximo, revelará detalhes e fatores que não são percebidos através de perspectivas mais generalizantes.

A respeito da diretora da unidade, faz-se necessário apresentá-la antes de passarmos a discutir o âmago de nosso problema de pesquisa. Trata-se de uma senhora que, de acordo com sinais fenotípicos percebidos por mim, é preta, possui licenciatura em química e é servidora do DEGASE desde 1994, 


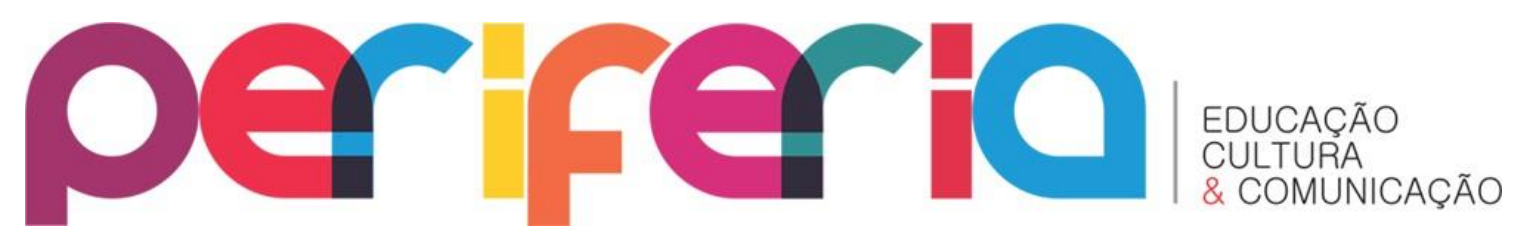

quando foi feito o primeiro concurso para preenchimento do quadro de servidores de carreira.

Ao longo de sua trajetória nesta instituição tornou-se muito conhecida devido ao fato de ter sido dirigente da unidade Padre Severino durante muitos anos e se destacando por quase sempre conseguir impor "ordem" em situações de conflito. Há dois anos e meio foi convidada, estrategicamente, para ser diretora da unidade a qual pesquisamos.

Sobre sua passagem no famoso Padre Severino, surge um dado muito importante revelado por ela e que dialoga bastante com a proposta deste trabalho de optar por uma escala mais reduzida, que neste caso se corporifica em ouvir uma voz que não seja a hegemônica e midiática.

Ao ouvirmos o nome PADRE SEVERINO ${ }^{3}$ automaticamente, nós, cariocas com idade a partir, mais ou menos, dos trinta anos, criamos em nosso imaginário uma figura muito bem delineada do que seria esta instituição, sobretudo nos anos 90 e início dos anos 2000. Qual carioca de meia idade nunca ouviu falar nas catastróficas rebeliões que lá ocorreram? Nas imagens precárias e de violência da unidade? Grande parte de nós "conhece muito bem" este local devido às inúmeras notícias quase que diárias que saíam em todas as mídias do Rio de Janeiro e do Brasil sobre esta unidade.

Nos revelando a importância de uma mudança de escala, a diretora entrevistada fez questão de se pronunciar acerca de sua longa e duradoura passagem nesta instituição "caricata". Revelou que grande parte das vezes em que a mídia noticiava ter havido rebeliões na unidade $e$ desordens/depredações por parte dos meninos, muitas vezes não passavam de meras atitudes normais esperadas de jovens com determinado perfil social e cultural.

3 Unidade de internação do Degase, situada à Estrada dos Maracajás, s/n, Galeão - Ilha do Governador. 


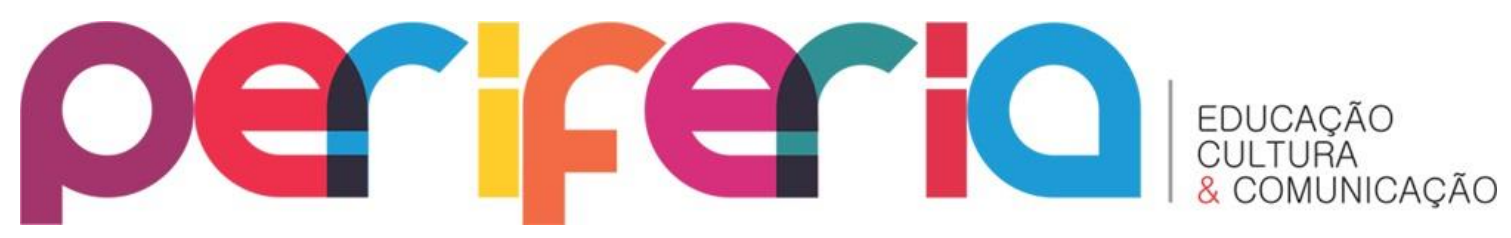

Figura 1: Rebelião no Padre Severino, em junho de 2002

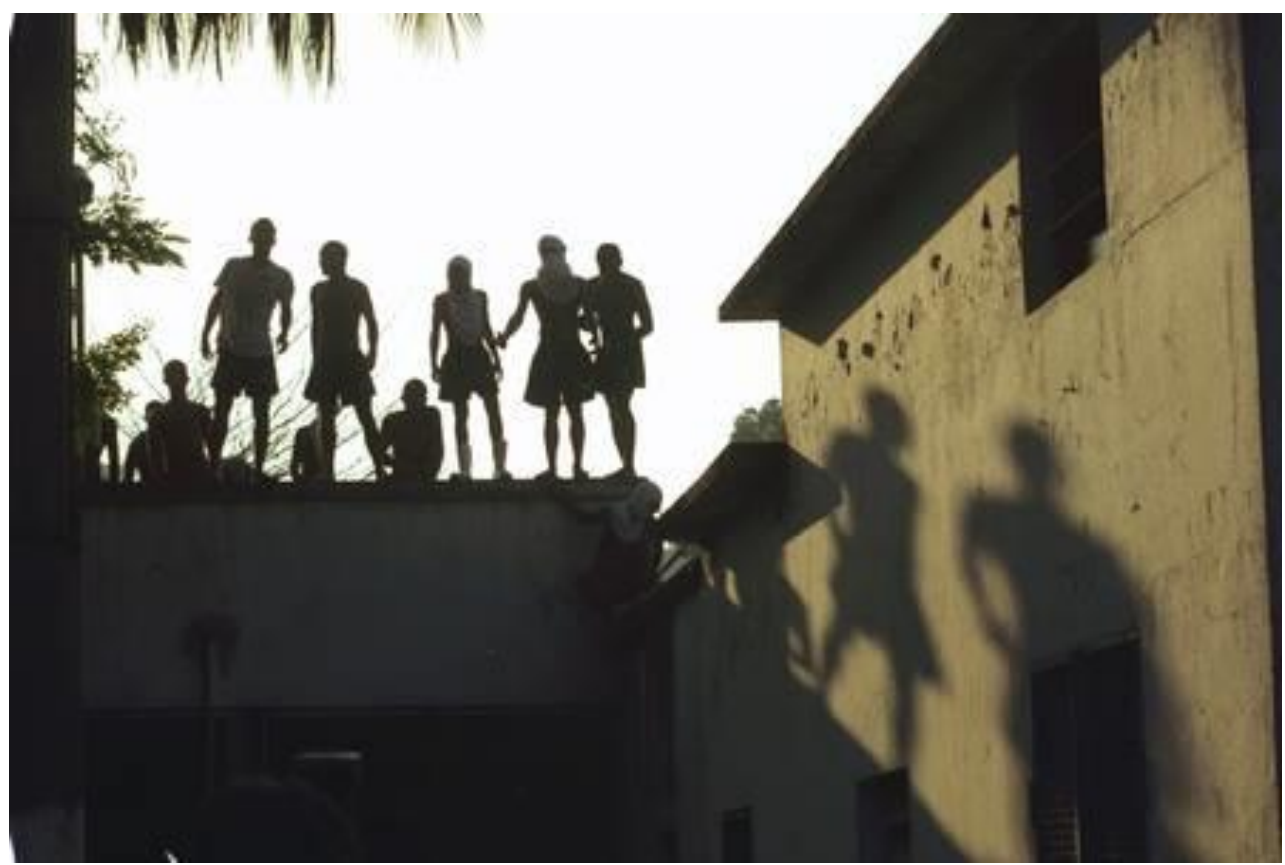

Fonte: Site do Jornal Extra - Foto: Eurico Dantas ${ }^{4}$

Relata que muitas vezes, por exemplo, uma briga pequena ocorrida entre colegas, em uma partida de futebol e que era facilmente contornada minutos após o ocorrido, pelos próprios meninos, era noticiada como tentativa de rebelião pela mídia nacional. Alega, também, que nunca foi desrespeitada pelos adolescentes de lá em todo o seu tempo de permanência e conta, inclusive, que muitos hoje em dia ao a encontrarem na rua fazem questão de cumprimentá-la e a tratam sempre com muito carinho.

Outro fato curioso relatado por ela e que merece atenção eram as notícias veiculadas sobre o comportamento "depredador" dos meninos de lá, fortemente veiculado pela imprensa ao relatarem, por exemplo, os danos ao patrimônio público realizados durante as verdadeiras rebeliões. Segundo entendimento dela, algumas condutas em rebeliões não são animalescas, criminosas, mas mera questão de sobrevivência, explicável pelo próprio

\footnotetext{
${ }^{4}$ Disponível em: http://extra.globo.com/casos-de-policia/unidades-para-menores-infratoresno-rio-tem-historico-de-rebelioes-agressoes-torturas-guerra-de-faccoes-13632677.html
} 


\section{periferio}

comportamento humano.

Nenhuma conduta diferente da que qualquer outro ser humano "de bem" teria em situação análoga, onde você ou arrebenta uma grade para fugir, utilizando o que tiver pela frente, ou você é assassinado pela facção rival que, após iniciar a rebelião sai à caça dos algozes. Discurso idêntico ouvi do diretor da unidade socioeducativa de Bangu, conhecida como Bangu Zero.

Como eu disse, essa pausa no assunto específico deste trabalho, focando um pouco na experiência desta diretora em sua passagem pelo Padre Severino, foi apenas para exemplificar a importância de uma mudança na escala da pesquisa, a importância de ouvir os sujeitos e visualizar os paradoxos existentes nas versões oficiais sobre alguns assuntos. A apresentação desta senhora enquanto sua experiência profissional é de grande valia, também, para a análise da característica sui generis desta unidade a qual ela atualmente dirige. Mas esta análise será feita em outro momento, visto que requer mais tempo e dedicação. Voltemos agora ao tema central deste trabalho.

\section{A DISCRIMINAÇÃO RACIAL NA UNIDADE}

Conforme exposto acima, as relações dentro do CRIAAD em questão, apesar de poucas vezes eclodirem e transformarem-se em grandes conflitos, geralmente acontecem sob muita tensão. Dentre os elementos geradores de tensão na unidade encontra-se a temática racial, seja diretamente relacionada ao problema, seja de forma transversal, segundo relatos da assistente social entrevistada.

Segundo ADORNO (1996), os preconceitos em relação a classe social e renda, são aumentados pelo preconceito étnico-racial. De acordo com o autor este critério contribui não só, mas também, para o cenário atual em que vemos grande parte da população brasileira excluída dos direitos, até mesmo os fundamentais. Segundo ele, negros e negras encontram-se no local mais baixo da pirâmide social brasileira. 


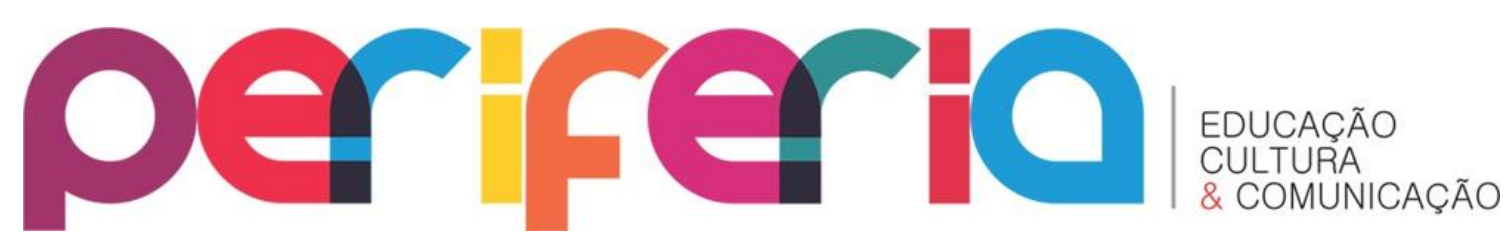

Visando analisar e descrever de que forma estas tensões com motivação racial ocorrem e como são enfrentadas (se são enfrentadas) e combatidas pela equipe responsável da unidade, registrei em um diário de campo todas as conversas que tive com uma assistente social e a diretora, além de aplicar um questionário semiestruturado ao pedagogo e à assistente social.

O pedagogo em questão está na instituição há dois anos, se autodeclara como negro e desempenha, na prática, as seguintes funções: acompanhamento escolar dos adolescentes, procedimentos para efetivação de matrícula escolar, orientação acerca da importância e valor da educação e contato com outras instituições para inclusão dos adolescentes em cursos internos e externos.

Alegou ter conhecimento acerca da lei 10.639/03, mas afirma não saber do que se trata o Plano Nacional de Implementação das Diretrizes Curriculares Nacionais para Educação das Relações Étnico Raciais e Para o Ensino de História e Cultura Afrobrasileira e Africana. Segundo ele não há, na unidade, atividades voltadas para a promoção da igualdade racial e o enfrentamento à discriminação racial. Alegou não possuir treinamento para tal e deixou em branco algumas indagações no questionário acerca das Diretrizes citadas acima. De acordo com minha observação, demonstrou pouca intimidade com o assunto, apesar de ter declarado, que reconhece a importância da implementação da Lei 10639/03.

De acordo com relatos da assistente social, que em conversa alegou presenciar de forma corriqueira episódios de discriminação racial entre os próprios assistidos, é muito frequente que os rapazes de cor branca submetam os colegas negros a situações em que estes se tornem seus submissos, de acordo coma as palavras dela, "seu bode expiatório".

Ela exemplifica esta afirmação com um fato que alega ser corriqueiro na unidade. Diz que geralmente os meninos encarregados de trazerem drogas para dentro do local são os meninos negros, geralmente detentores de menor renda em relação aos brancos, e que geralmente fazem isso instigados por estes últimos, a fim de que mantenham dentro da unidade seus vícios sem 


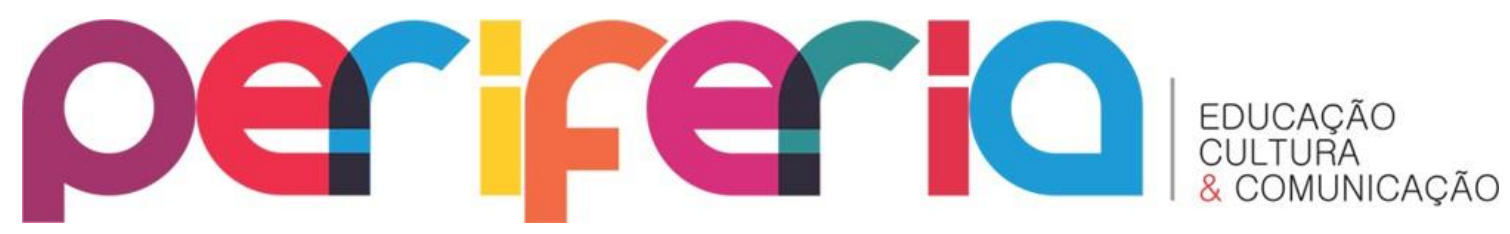

serem flagrados descumprindo ordens, o que poderia acarretar um endurecimento da medida e até mesmo a perda do direito de continuar na semiliberdade.

Agindo desta forma meninos brancos mantém seus vícios e seus privilégios no recinto às custas de colocar em risco as garantias de seu companheiro de pele negra e, geralmente o chamado "bode expiatório" arca com as consequências, por muitas vezes ser flagrado na revista tentando entrar com drogas na unidade. Ela ainda acrescenta que são frequentes as injúrias raciais proferidas entre eles e geralmente o meio como eles lidam com esta agressão em desfavor de sua raça/etnia é de forma violenta.

Uma boa reflexão e compreensão teórica acerca da atitude relatada acima se encontra nas palavras de Adorno (1996, p.284.), ao alegar que:

há um consenso quanto aos efeitos provocados pelo efeito discriminatório das agências encarregadas de conter a criminalidade: a intimidação policial, as sanções punitivas e a maior severidade no tratamento dispensado àqueles que se encontram sob tutela e guarda nas prisões recaem preferencialmente sobre "os mais jovens, os mais pobres e os mais negros". São estes os grupos justamente desprovidos das imunidades conferidas para as complexas organizações delinqüentes envolvendo cidadãos procedentes das classes médias e elevadas da sociedade.

Apesar do trecho acima se referir à conduta do Estado para com as populações negras de jovens em conflito com a lei, esta mesma lógica se aplica dentro das unidades de cumprimento de medida entre os próprios adolescentes tutelados, onde o ser branco encontra-se em situação de privilégio e poder, e apesar de sua condição de semi-interno ainda goza dos benefícios de sua cor.

O mais curioso desta situação do "bode expiatório" é que mesmo o poder público sabendo, através de seu servidor, que a conduta proibida de “fazer a missão" de levar drogas para dentro da unidade não foi uma conduta isolada, mas sim premeditada por alguém, solicitada por alguém e que a droga trazida seria compartilhada com esse alguém (às vezes até de forma 


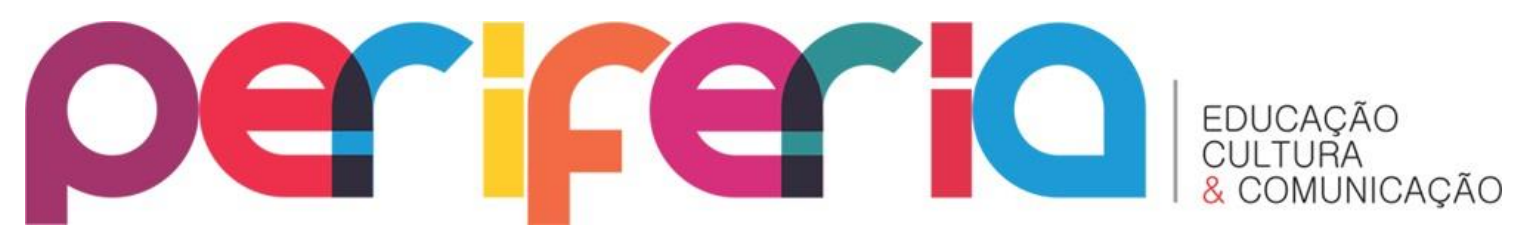

onerosa, mediante pagamento), ainda assim só se pune o "bode" preto. Ou seja, sua cor serve como critério de punição durante seu processo de judicialização, vigilância policial e durante o cumprimento da medida.

Apesar de, particularmente, possuir uma visão acerca da lei de drogas muito diferente e oposta da visão oficial e não acreditando que a sua proibição seja o caminho, penso que se o que vale é o princípio da impessoalidade, o papel do agente público é exercer o seu trabalho dentro da legalidade (atendendo ao que diz a lei sobre cada caso) independente de critérios de raça, cor e renda. Mas como diz o autor em comento, "se o crime não é privilégio da população negra, a punição parece sê-lo” (ADORNO, 1996. p.1).

Outro traço de atitude preconceituosa e que, segundo ela, possui ligação com o tema raça é a intolerância religiosa existente na casa em relação às religiões de matrizes africanas. De acordo com os acompanhamentos individuais que realiza com os jovens, ela disse ter diversas vezes percebido que uma parte significante dos meninos possui ligações com estas religiões, mas curiosamente, ao preencherem o questionário constante na ficha de recepção, alegam no campo "pertencimento religioso" pertencerem a religião professada pelos familiares (geralmente mãe), declarando pertencerem ao catolicismo ou ao protestantismo.

Explica que tomou conhecimento desta praxe na casa a partir do momento em que passou a prestar atenção nas conversas entre os rapazes, ouvindo coisas do tipo: "a mãe lá do centro está cuidando de mim", "não posso fumar maconha porque estou usando a guia", "na hora em que o santo baixou", "neste fim de semana vou ao terreiro", entre outros fragmentos de conversa e por ter recebido na unidade, algumas vezes, a sacerdote encarregada do centro frequentado por um dos meninos, que ia até o CRIAAD a fim de visitar o menino.

Observou, também, que há um menino na unidade que possui uma guia e que não a coloca no pescoço, apenas anda constantemente com ela no bolso, por medo de ao ser visto com um objeto que remeta a religiões de 


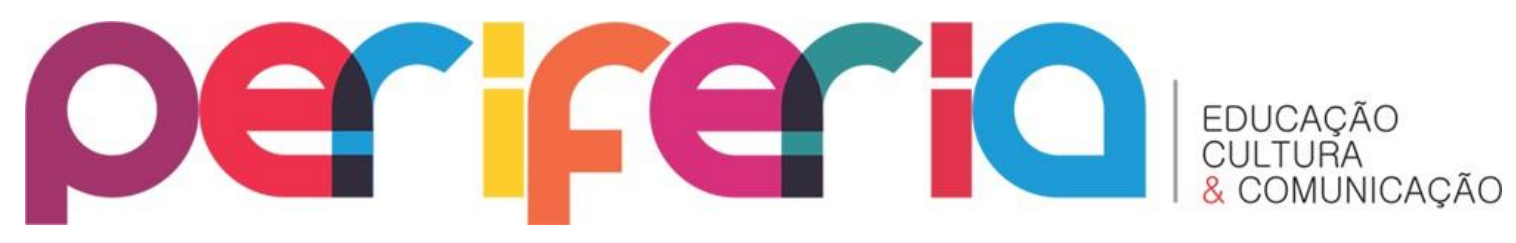

matrizes africanas, sofrer algum tipo de retaliação por parte dos demais colegas que não professam a mesma fé. Segundo seus relatórios de recepção de adolescentes, ela só recebeu um menino, em seus vinte e um meses de unidade, que alegou por escrito no formulário, pertencer à Umbanda.

Ao ser indagada sobre a existência de atividades na unidade que visem o combate, o enfrentamento ao racismo e promoção da igualdade racial, bem como difusão da história e da cultura afrobrasileira e africana, ela alega que realizada diretamente pela equipe não há. Diz que reconhece a importância destas abordagens, mas que infelizmente não possuem treinamento adequado por parte da Direção Geral do DEGASE.

Afirma que em todos os cursos de capacitação, treinamento e formação promovidos pelos órgãos dirigentes da instituição os temas "questão racial” e “promoção da igualdade racial” são sempre mencionados, porém apenas enunciativa.

Diz ter pleno conhecimento da Lei $\mathrm{n}^{\circ} 10.639 / 03$ e das diretrizes e reconhece "a importância de tais instrumentos em um país cujos processos de formação social encarregaram-se de apagar e subjugar a importância dos afrodescendentes". Relata que tentou promover algumas atividades relacionadas a esta temática com os meninos e com suas famílias, mas que se sentiu desconfortável de trabalhar tal temática por alegar que seu lugar de fala é diferenciado, por ser branca e possuir privilégios que foram furtados da maioria dos meninos com os quais trabalha e suas famílias.

Segundo ela, em suas tentativas de trabalhar o tema em questão, ela desenvolvia discussões com os meninos acerca dos aspectos que os identificava uns com os outros, estimulando-os a chegarem ao critério raça como elemento comum a todos eles, para então fomentar neles a reflexão acerca de sua realidade enquanto jovens negros e periféricos. Conta que esta mesma atividade foi feita com o chamado grupo familiar, ou seja, nas reuniões semanais com as mães dos socioeducandos.

De acordo com suas declarações, há resistência entre os meninos e suas famílias ao tocar nesta temática nas atividades em que ela tentou realizar. 


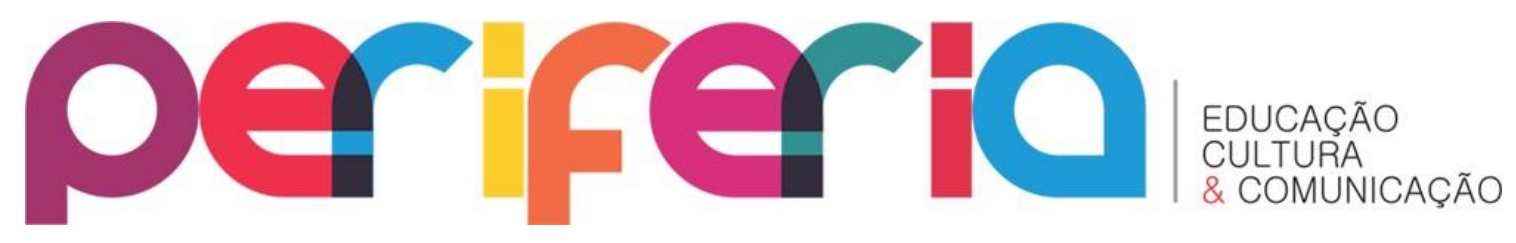

Disse que quase sempre achavam que ela estava querendo propagar religiões afrobrasileiras e que por este motivo as tentativas não foram tão proveitosas.

Aponta ainda que a discriminação racial não se expressa apenas entre os jovens ali presentes. Relata um fato que ela denomina como incoerente, onde uma determinada escola pública do Município, que por lei é obrigada a atender meninos da unidade e que se destaca por realizar atividades que visam a valorização e promoção da cultura e história afrobrasileira e africana, recusou-se a matricular jovens negros do CRIAAD Nova Iguaçu, sob o argumento de não quererem menores infratores em seu corpo discente.

\section{CONSIDERAÇÕES FINAIS}

Ao iniciar esta pesquisa, procurei em livros e documentos um conceito seguro acerca do que vem a ser o termo "socioeducação". Após buscas em legislações e doutrinas, percebi tratar-se de uma palavra cujo significado ainda é uma lacuna nas legislações brasileiras. Este termo surgiu com a implementação do Estatuto da Criança e do Adolescente, no ano de1990, que institui medidas "socioeducativas" ao adolescente em conflito com a lei. Vale ressaltar que a conceituação aqui necessária distancia-se um pouco da conceituação de Paulo Freire, tendo em vista a concepção necessária do termo para este trabalho ter a necessidade de sua abordagem jurídica, e não apenas pedagógica.

A partir deste marco nos aparece juridicamente este termo, que apesar de não possuir definição legal, é compreendido pelos seus operadores (funcionários do Departamento Geral de Ações Socioeducativas (DEGASE) como sendo "um conjunto de ações interdisciplinares e integradas, de caráter sócio pedagógico, que possuem como função precípua reintegra os indivíduos na vida social preparando-os para a vida" (de acordo com a fala assistente social).

Quando definimos a função do ato socioeducativo como "preparar os indivíduos para a vida social", nos deparamos com um parâmetro universal 


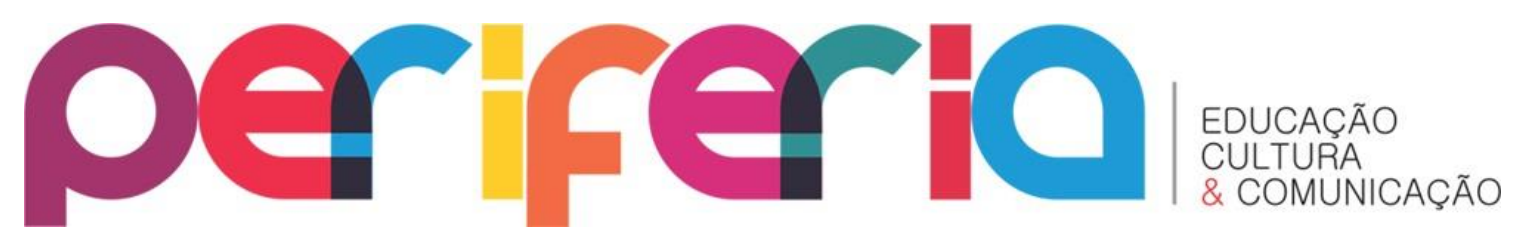

sobre os fins da socioeducação, e desta forma podemos descrevê-lo como a função de formar os indivíduos para o exercício da cidadania, termo este que por muitas vezes foi furtado deste adolescente, de forma a culminar em sua passagem por instituições como a que pesquisamos neste trabalho.

Se considerarmos o termo cidadania como o gozo de plenos direitos e deveres civis, políticos e sociais e a função da socioeducação como sendo a de preparar o adolescente em conflito com a lei para este exercício, passamos a entender que é, também, função do sistema em questão trabalhar com este jovem o tema da diversidade etnicorracial, tendo em vista ser o direito constitucional a igualdade, uma reflexão da cidadania, assim como o direito a conhecer suas origens, professar uma religião e não ser discriminado por raçacor ou pertencimento religioso.

Partindo deste princípio analiso que este trabalho se torna importante, tendo em vista os índices crescentes de encarceramento da juventude negra e seu extermínio. É necessário que entidades que trabalham com populações privadas de liberdade (ou semiprivadas) estejam em constante contato com este tema, que se encaixa no rol de direitos humanos.

Não devemos observar a obrigatoriedade do ensino da história e cultura afro-brasileira e africana apenas como um tema a ser debatido obrigatoriamente em sala de aula, tendo em vista o fato de a escolarização em nosso país ser um privilégio de classe e de cor, mas sim em todos os segmentos da sociedade, principalmente em instituições cuja predominância de sujeitos é da cor preta.

O empoderamento da juventude negra encarcerada é essencial para que se apropriem de sua identidade étnico racial, sua autoestima e sua representatividade. Tomar conhecimento de sua história, suas origens e reconhecer em sua raça (etnia) valor é de suma importância para que haja um reajuste social. Tratar o seu encarceramento como um problema ligado a questões raciais históricas é fundamental para que superem esta condição para a qual foram socialmente empurrados.

Também se torna indispensável esta temática tendo em vista as 


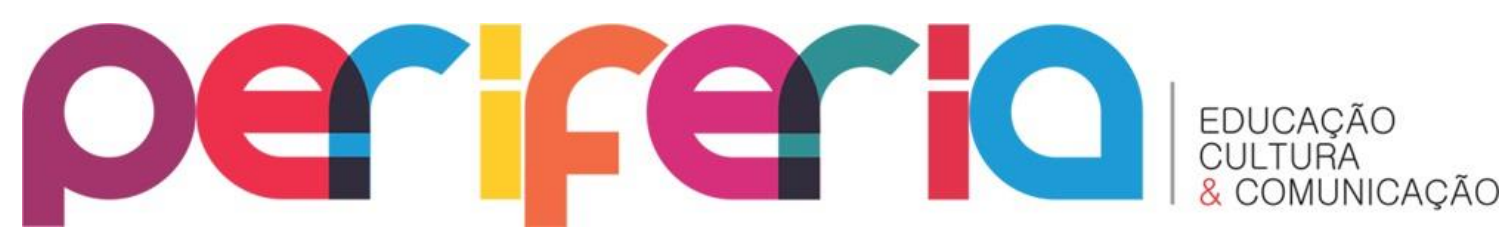

relatadas tensões raciais existentes no CRIAAD Nova Iguaçu, que devem servir como motivação para que medidas urgentes sejam tomadas, no sentido de promover a igualdade racial e o combate ao racismo.

Informações trazidas por este trabalho, como o critério de definição de cor adotado pelo DEGASE, conforme o formulário constante no anexo I deste trabalho, é importante a fim de que discutamos de que forma e que critérios esta instituição utiliza para classificá-los. Há uma clara noção de que confundem preto com negro, o que se torna um dado importante para que se realize uma discussão acerca do que significa ser negro na concepção deste instituto.

Esta constatação reforça ainda mais a necessidade de que as temáticas: raça, racismo, discriminação racial, empoderamento negro, entre outras, devem ser trabalhadas não só com os assistidos, mas também com os servidores. A fim de que tentem colocar em voga tal temática, a utilização de obras cinematográficas nacionais pode ser de grande auxílio para se começar a trabalhar de forma lúdica, atrativa e proveitosa tais temáticas entre os jovens. Sugiro a utilização de obras fílmicas, tendo em vista o fato de os meninos desta unidade quase sempre solicitarem "sessões de cinema" improvisadas na unidade quando questiono o que gostariam de ter como atividades futuras.

Filmes como Do Meu lado (Tarcísio Lara Puiati - 2014) ${ }^{5}$, Vista minha Pele (Joel Zito Araújo -2003) ${ }^{6}$, Menino 23 (Belisário França - 2016) ${ }^{7}$, Última Parada 174 (Bruno Barreto - 2008) ${ }^{8}$, Negros Dizeres (Hugo Lima, 2015) ${ }^{9}$, A

\footnotetext{
${ }^{5}$ Curta Metragem pertencente à coletânia "Décima Mostra de Cinema e Direitos Humanos", distribuída através de edital pela Secretaria de Direitos Humanos da Presidência da República ao CRIAAD Nova Iguaçu.

${ }^{6}$ Disponível em: https://youtu.be/FRq4fkkm5Iw. Acesso em: fevereiro de 2017.

${ }^{7}$ Documentário dirigido por Belisário França. Apesar de não estar disponível na internet, a produtora realiza sessões de exibição do documentário, de forma gratuita, em escolas, universidades e espaços culturais, através de solicitação via e-mail.

${ }^{8}$ Disponível em:

https://youtu.be/tv55oDw5VJI?list=PL7TD5nGlqSoCl5kHOU3zMgKXYbB1Kcn4J. Acesso em: fevereiro de 2017

${ }^{9}$ Disponível em: https://youtu.be/yjYtLxiVQ7M Acesso: fevereiro de 2017.
} 


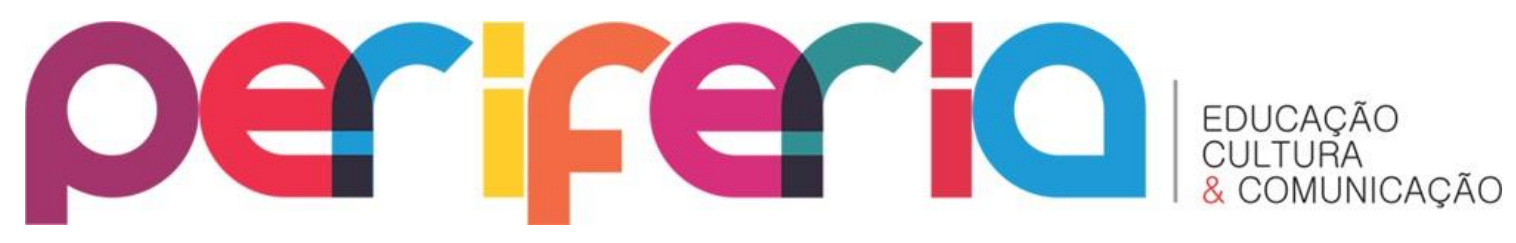

Negação do Brasil (Joel Zito Araújo - 2001) ${ }^{10}$, Branco Sai, Preto Fica (Adirley Queirós, 2014) $)^{11}$, são boas ferramentas para chamar a atenção para a temática entre os jovens e abrir caminhos para discussões futuras mais profundas com os sujeitos, através de rodas de conversa, debates e palestras, após este momento introdutório de trabalho com filmes.

A proposta aqui apresentada, apesar de se direcionar ao trabalho com os adolescentes, pode ser feita com a equipe técnica da unidade, a fim de que anteriormente compreendam e reconheçam a importância da temática no meio onde exercem suas funções.

É muito interessante que uma parte da equipe técnica da unidade reconheça a necessidade de políticas voltadas a este fim e a sua incapacidade/despreparo para trabalhar tais discussões. Sabemos que durante muitos anos, no Brasil, pairou/pairava/paira o mito da democracia racial, constituindo-se como fator impeditivo de uma política voltada para o combate ao racismo, a partir da negação deste. Desta forma, reconhecer que há uma questão racial e que esta deve ser tratada, é um passo determinante para sua superação.

\section{REFERÊNCIAS}

ADORNO, Sergio. Racismo, criminalidade violenta e justiça penal: réus brancos e negros em perspectiva comparativa. Revista Estudos Históricos. Volume 9. Número 18. Rio de Janeiro: Fundação Getúlio Vargas, 1996. Disponível em: http://bibliotecadigital.fgv.br/ojs/index.php/reh/article/view/2034/1173. Acesso em: dezembro de 2016.

ALVES, José Cláudio Souza. Dos barões ao extermínio: uma história da violência na Baixada Fluminense. Duque de Caxias, RJ: APPH, CLIO, 2003. P.15.

A NEGAÇÃO do Brasil. Direção: Joel Zito Araújo. 2001. Duração: 1h 32 min Disponível em: https://youtu.be/6HAgWlUug5c Acesso: fevereiro de 2017

BEZERRA, Nielson Rosa. Mosaicos da escravidão: identidades africanas e

\footnotetext{
${ }^{10}$ Disponível em: https://youtu.be/6HAgWlUug5c Acesso: fevereiro de 2017

${ }^{11}$ Disponível em: https://youtu.be/j_6Lcu4L2mk. Acesso em: fevereiro de 2017
} 


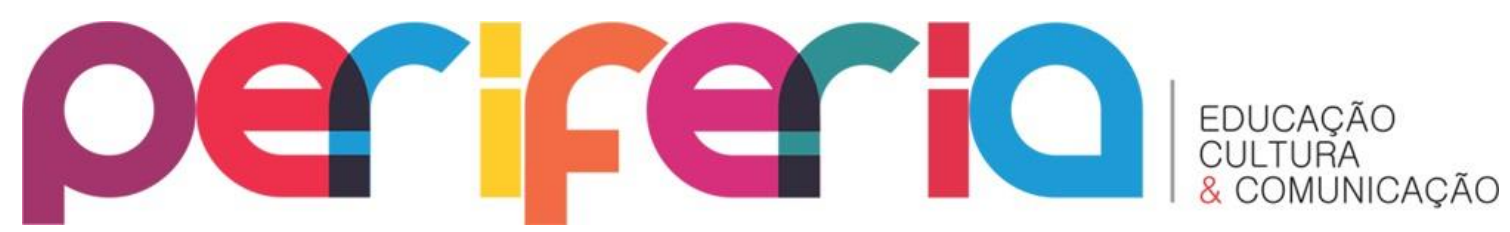

conexões atlânticas do Recôncavo da Guanabara (1780-1840). Niterói. Tese (Doutorado)- Universidade Federal Fluminense, Instituto de Ciências Humanas e Filosofia, Departamento de História, 2010. Disponível em:

http://www. historia.uff.br/stricto/td/1235.pdf. Acesso em: fevereiro de 2017.

BRANCO sai, preto fica. Direção: Adirley Queirós. 2014. Duração: $1 \mathrm{~h} 33$ min. Disponível em: https://youtu.be/j_6Lcu4L2mk. Acesso em: fevereiro de 2017.

BRASIL. Sistema Nacional de Atendimento Socioeducativo - SINASE. Brasília: CONANDA e Secretaria Especial dos Direitos Humanos. 2013. Disponível em: http://www.sdh.gov.br/noticias/pdf/levantamento-2013. Acesso em:

Fevereiro de 2017

. Estatuto da Criança e do Adolescente. Brasília: Presidência da República. 1990. Disponível em: http://www.planalto.gov.br/ccivil_03/leis/L8069.htm. Acesso em fevereiro de 2017.

- Diretrizes curriculares nacionais para a educação das relações étnicoraciais e para o ensino de história e cultura afro-brasileira e africana. Brasília: Conselho Nacional de Educação. 2004. Disponível em: http://www.acaoeducativa.org.br/fdh/wp-content/uploads/2012/10/DCN-sEducacao-das-Relacoes-Etnico-Raciais.pdf. Acesso em: fevereiro de 2017.

DO MEU lado. Direção: Tarcísio Lara Puiati. Brasília: DVD Décima Mostra de Cinema e Direitos Humanos - Secretaria de Direitos Humanos Presidência da República (SDH). 2014. Duração: 14 minutos.

LEVI, Giovanni. Sobre a micro-história. In: BURKE, Peter (org). A escrita da história: novas perspectivas. São Paulo: Editora da UNESP, 1992.

MENINO 23. Direção: Belisário França. Brasil. 2016. Duração: 1h 19 min.

NEGROS Dizeres. Direção: Hugo Lima. Brasil 2015. Duração: 42 minutos Disponível em: https://youtu.be/yjYtLxiVQ7M Acesso: fevereiro de 2017.

ROCHA, André dos Santos. "Nós não temos nada a ver com a Baixada!" problemáticas de uma representação hegemônica na composição do território. Rio de Janeiro. Recôncavo: Revista de História da UNIABEU. Vol. 3, N. 4, 2013.

SIMÕES, Manoel Ricardo. A cidade estilhaçada: reestruturação econômica e emancipaçõos municipais na baixada fluminense. Niterói: Tese (Doutorado) Departamento de Geografia do Instituto de Geociências da Universidade Federal Fluminense. 2006. Disponível em: http://www.bdtd.ndc.uff.br/tde_arquivos/26/TDE-2010-04-19T123855Z- 


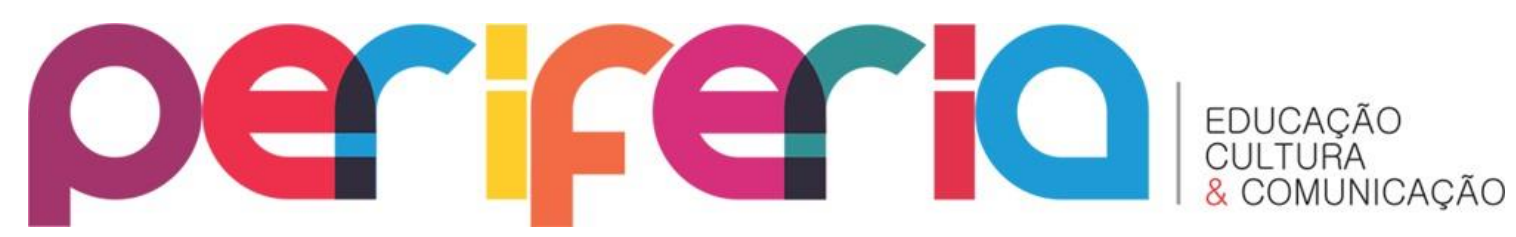

2423/Publico/D\%20Manoel\%20Ricardo\%20Simoes-Tese.pdf. Acesso em: fevereiro de 2017.

ÚlTIMA Parada 174. Direção: Bruno Barreto. Moonshot Pictures. Brasil. 2008. Duração: $1 \mathrm{~h} 50$ min. Disponível em:

https: / /youtu.be/tv55oDw5VJllist=PL7TD5nGlqSoCl5kHOU3zMgK. Acesso em: fevereiro de 2017.

VISTA minha pele. Direção: Joel Zito Araújo. Brasil. 2003. Duração: 24 minutos. Disponível em: https://youtu.be/FRq4fkkm5lw. Acesso em: fevereiro de 2017. 